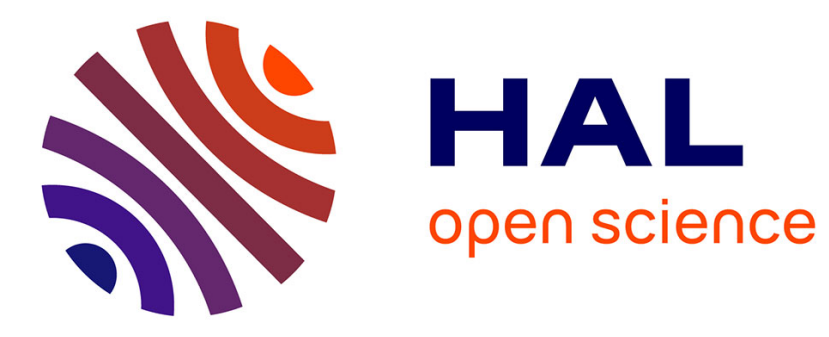

\title{
Severe spp. infections: new insights into natural immunity
}

Jos W.M. van Der Meer, Frank L. van de Veerdonk, Leo A.B. Joosten, Bart-Jan Kullberg, Mihai G. Netea

\section{- To cite this version:}

Jos W.M. van Der Meer, Frank L. van de Veerdonk, Leo A.B. Joosten, Bart-Jan Kullberg, Mihai G. Netea. Severe spp. infections: new insights into natural immunity. International Journal of Antimicrobial Agents, 2010, 36, 10.1016/j.ijantimicag.2010.11.013 . hal-00650374

\section{HAL Id: hal-00650374 https://hal.science/hal-00650374}

Submitted on 10 Dec 2011

HAL is a multi-disciplinary open access archive for the deposit and dissemination of scientific research documents, whether they are published or not. The documents may come from teaching and research institutions in France or abroad, or from public or private research centers.
L'archive ouverte pluridisciplinaire HAL, est destinée au dépôt et à la diffusion de documents scientifiques de niveau recherche, publiés ou non, émanant des établissements d'enseignement et de recherche français ou étrangers, des laboratoires publics ou privés. 


\section{Accepted Manuscript}

Title: Severe Candida spp. infections: new insights into natural immunity

Authors: Jos W.M. van der Meer, Frank L. van de Veerdonk, Leo A.B. Joosten, Bart-Jan Kullberg, Mihai G. Netea

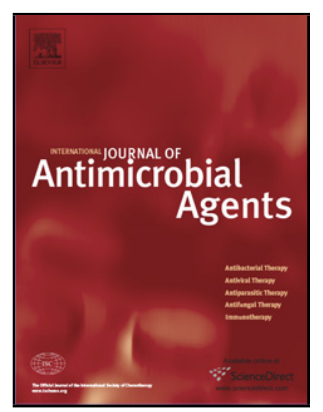

PII:

S0924-8579(10)00474-7

DOI: doi:10.1016/j.ijantimicag.2010.11.013

Reference: ANTAGE 3467

To appear in: International Journal of Antimicrobial Agents

Please cite this article as: van der Meer JWM, van de Veerdonk FL, Joosten LAB, Kullberg B-J, Netea MG, Severe Candida spp. infections: new insights into natural immunity, International Journal of Antimicrobial Agents (2010), doi:10.1016/j.ijantimicag.2010.11.013

This is a PDF file of an unedited manuscript that has been accepted for publication. As a service to our customers we are providing this early version of the manuscript. The manuscript will undergo copyediting, typesetting, and review of the resulting proof before it is published in its final form. Please note that during the production process errors may be discovered which could affect the content, and all legal disclaimers that apply to the journal pertain. 


\section{Severe Candida spp. infections: new insights into natural immunity}

Jos W.M. van der Meer*, Frank L. van de Veerdonk, Leo A.B. Joosten, Bart-Jan Kullberg, Mihai G. Netea

Dept. Internal Medicine and Nijmegen Institute for Infection, Inflammation and Immunity (N4i), Radboud University Nijmegen Medical Centre, Nijmegen, The Netherlands

* Corresponding author. Tel.: +31 243614763.

E-mail address: J.vandermeer@aig.umcn.nl (J.W.M. van der Meer). 


\begin{abstract}
Invasive infections caused by Candida spp. are associated with high mortality. Colonization by Candida spp. and the capacity of the host to recognize them as potential pathogens are essential steps in the development of these infections. The major pathogen-associated molecular patterns of Candida are mannoproteins, glucans and chitins, which are recognized by C-type lectin pattern recognition receptors such as the mannose receptor, dectin-1 and dectin-2. By the secretion of proteases and toxins, and the formation of hyphae and biofilms, Candida spp. are able to enhance their virulence and pathogenicity. Studies in patients with relatively rare immunodeficiencies, such as dectin-1 deficiency, CARD9 deficiency, chronic mucocutaneous candidiasis, hyper-IgE/Job's syndrome and chronic granulomatous disease, have shown the role of dectin-1 and its signalling pathway, which involves interleukins 17 and 22, defensins and phagocytic cells, in defence against Candida. These studies also provide insights into how acquired risk factors for fungal infection operate, and may lead to new approaches for immunotherapy.

Keywords:

Candida

Invasive fungal infection

Pathogen-associated molecular patterns

Interleukins
\end{abstract}




\section{Introduction}

Invasive infections caused by Candida spp. are a major healthcare problem in modern medicine [1]. These yeasts rank as the fourth most common bloodstream pathogen in hospitals in the Western world [2,3] but are associated with the highest mortality among bloodstream infections.

In healthy subjects Candida spp., especially $C$. albicans, are present as a commensal. Colonization by Candida spp. is almost always the first step in the development of invasive candidiasis. Many exogenous and endogenous factors may lead to impaired host defence against Candida spp. and, as a consequence, Candida may disseminate into the bloodstream and infect multiple organs [1]. In this paper we take a stepwise approach to reviewing the pathogenesis of severe Candida infections and incorporate insights from recent research.

\section{Candida spp. colonization of mucosal surfaces}

At least $30 \%$ of healthy individuals are colonized with $C$. albicans at any given moment [1]. The body sites that Candida preferably colonize are the oropharynx, vagina and skin, especially skin folds (axilla, groin, perineum). Candida produce proteolytic enzymes (such as aspartyl proteinases and phospholipases) and toxins (such as mycotoxin) that affect host defences and enhance their chances of colonizing and invading the host [4-6]. In addition, Candida have the ability to switch phenotype to a more virulent form that spontaneously produces mycelia [7], but it is unclear to what extent this occurs at various sites in vivo [8]. The numbers of Candida organisms at different body sites is under the control of other locally colonizing flora, especially bacteria. The exact mechanisms by which bacteria control colonization by yeast are only partially understood. Competition for nutrients is considered a major explanation. In the vagina, lactobacilli not only compete for nutrients but also produce hydrogen peroxide, bacteriocins and lactic acid, which create an environment that is hostile to Candida spp. [8]. When the colonizing bacterial flora is destroyed by treatment with antibiotics, especially broad-spectrum drugs, yeast colonization will increase.

In diabetic patients, the high glucose content of the tissues is thought to enhance yeast colonization. Oestrogens lead to increased vaginal yeast colonization by enhancing the glycogen content of the vaginal epithelial cells, thereby providing a nutritional source for Candida [9]. In addition, Candida spp. possess a cytosolic receptor-like structure that induces mycelial formation after exposure to oestrogen [10]. These mechanisms may be responsible for the increased vaginal Candida colonization and frequency of symptomatic candidiasis in pregnancy and after the use of contraceptives with high-dose oestrogen [8].

\section{Colonization and infection}

An important question is how the host is able to discern between harmless Candida cells colonizing the epithelium and Candida cells that are pathogenic. Here, Janeway's concept of pattern recognition receptors interacting with the surface molecules of pathogens called pathogen-associated molecular patterns (PAMPs) is of key relevance [11]. Several families of pattern recognition receptor have been described: the Toll-like receptors, the C-type lectin receptors, the nucleotide-binding domain leucine-rich repeat-containing receptors, and the retinoic acid-inducible gene I receptors [12].

Much has been learned in recent years about the components of the cell wall of $C$. albicans. Mannans, mannoproteins, $\beta$-glucans and chitin, considered to be PAMPs [13], are essential for the structure of Candida. Chitin and $\beta$-glucans provide the necessary rigidity of the internal skeleton, while a heavily mannosylated layer of mannoproteins covers this layer and forms the surface (Fig. 1.). The mannoproteins, which are utilized by Candida to adhere to the epithelial surface, are recognized by the mannose receptor and dectin- $2, \beta$-glucans by dectin1 , and chitin by an as yet unidentified receptor. 
Most of the research into pattern recognition receptors has focused on their presence on white blood cells, and hence the importance of PAMPs on the epithelial cells of the skin and the mucous membranes of the pharynx, gastrointestinal tract, airways and urogenital tract is not fully appreciated.

These insights have enabled us recently to recognize a mild, rather selective immunodeficiency, dectin-1 deficiency [14]. In a family with three female siblings with chronic onychomycosis and recurrent vulvovaginal candidiasis, we demonstrated that their white blood cells did not produce cytokines when exposed to $\beta$-glucans. An abnormality of the cellular receptor dectin-1 was therefore suspected. Sequencing of their dectin-1 gene yielded a tyrosine at position 238 , leading to a stop codon. As a consequence a cysteine bond is lost, the three-dimensional conformation of the dectin- 1 extracellular domain is lost and the molecule is not expressed at the cell membrane. Heterozygotes with this mutation are not extremely rare and population studies have shown that it has to be considered an old mutation [14]. A propensity for more heavy colonization with Candida spp. was demonstrated in heterozygous patients within a cohort of allogeneic bone marrow transplant recipients [15]. A similar clinical picture to homozygous dectin-1 deficiency is seen in the homozygous CARD9 mutation that has recently been described [16]. This is not unexpected, as CARD9 is a signalling molecule downstream of dectin- 1 .

\section{4. $T_{h} 17$ lymphocytes and defensins}

In the subepithelial tissues, $T$ lymphocytes play a sentinel role in the defence against fungi. Research in our laboratory has demonstrated that $C$. albicans is the most potent known inducer of the differentiation of $T$ helper lymphocytes $\left(T_{h}\right)$ into the $T_{h} 17$ phenotype [17]. The Candida mannan and $\beta$-glucan PAMPs are responsible for the induction of the $\mathrm{T}_{\mathrm{h}} 17$ response [17]. There is evidence that complement activation, especially factor $\mathrm{C} 5 \mathrm{a}$, contributes to the induction of $\mathrm{T}_{\mathrm{h}} 17$ [18]. The $\mathrm{T}_{\mathrm{h}} 17$ lymphocytes (and also CD4-/CD8- $\mathrm{T}$ cells expressing T-cell receptor $\gamma \delta$ ) produce and secrete the proinflammatory cytokines interleukin (IL)-17 and IL22 , and these cytokines in turn induce the production of $\beta$-defensins by epithelial cells (Fig. 2.) $[19,20]$. $\beta$-defensins are cationic, amphiphilic, antimicrobial peptides of $12-50$ amino acids; as they have antifungal activity they are able to limit the outgrowth of colonizing Candida [21]. The patients with dectin-1 deficiency described above also have decreased IL17 production [14].

When there is a lack of control by CD4+ lymphocytes, as occurs in HIV infection, idiopathic CD4 lymphocytopenia or after treatment with the anti-CD52 monoclonal antibody alemtuzumab, an increased outgrowth of Candida spp. may occur, leading to infection [22]. Patients with rare immunodeficiency disorders, such as hyper-IgE/Job's syndrome (HIES) and chronic mucocutaneous candidiasis, suffer from mucocutaneous candidiasis (Fig. 2. and Fig. 3.) because of a lack of production of IL-17, IL-22 and $\beta$-defensins [23-25]. Because IL-17 also induces chemokines (e.g. IL-8) and the growth factor granulocyte colonystimulating factor (G-CSF), it induces the differentiation and migration of neutrophils (Fig.

4.) and thereby contributes to natural immunity when Candida has gained access to subepithelial tissues [26]. Such invasion may occur when there is physical or chemical damage to the epithelium.

Deficiency of IL-17 and IL-22, as occurs in the clinical disorders mentioned above, may thus predispose to more deep-seated Candida infection.

\section{Yeasts, hyphae and invasiveness}

When colonizing the epithelial surface, Candida spp. tend to be present only as yeasts, but when invading the tissues the yeast cells germinate and form hyphae. Hyphae are necessary for tissue invasion, as has been shown experimentally using Candida mutants that are unable to germinate at $37^{\circ} \mathrm{C}$ [27]. Whether the host responds in a different way to yeasts and hyphae is not known. 
During invasion of the tissues Candida encounter resident macrophages and this leads to the induction of mRNA for cytokines such as IL-1 $\beta$ and IL-18. These are produced as inactive precursors and for processing into active cytokines the inflammasome, a cytoplasmic protein platform [28], has to be activated in order to produce active caspase 1 (formerly called IL-1 converting enzyme). Whether Candida alone are able to activate the inflammasome, and if so by which components, is currently unknown. Neutrophils and monocytes (exudate macrophages) recruited to the site of infection will phagocytose and kill Candida, and in addition contribute to cytokine production (Fig. 5.). By contrast with macrophages, monocytes dispose of bioactive caspase- 1 and thereby readily process and secrete IL-1 $\beta$ [29]. The most serious invasive Candida infections tend to develop in patients with abnormal neutrophil recruitment, neutrophil dysfunction and, not least, in patients with severe neutropenia [30]. As mentioned above, a deficiency of IL-17, as occurs in HIES, will lead to insufficient neutrophil recruitment from the bloodstream. The cold abscesses that are a hallmark of HIES, and led to its original description as Job's syndrome [31], are a consequence of the poor influx of neutrophils. The most common acquired cause of defective neutrophil recruitment is treatment with glucocorticosteroids and other immunosuppressive drugs. The mechanisms by which glucocorticosteroids affect host defences are multiple [32]. A major mechanism is interference with the expression of adherence molecules on white blood cells [33]. In addition, corticosteroids inhibit the production of IL-17 [34]. A detailed discussion of the mechanisms by which other immunosuppressants affect host defence is beyond the scope of this paper.

The best-studied example of neutrophil dysfunction is, without doubt, chronic granulomatous disease, the group of hereditary phagocyte disorders in which there is defective generation of reactive oxygen intermediates (such as superoxide) due to a mutated NADPH cytochrome oxidase (or one of the proteins of the oxidase complex) in the membrane of the phagocytic cells [35]. Both neutrophils and monocyte/macrophages are defective in chronic granulomatous disease. Although Aspergillus spp. infections are the greatest threat to these patients, severe invasive Candida infections are quite common [36].

With regard to neutropenia, patients with neutropenia induced by chemotherapy or Xirradiation are at greater risk than those with one of the congenital neutropenia syndromes. The mucosal damage inflicted by chemotherapy or X-rays helps Candida to invade the tissues. An additional risk factor is broad-spectrum antibiotics [3], as they enhance the numbers of Candida by interfering with bacterial colonization at body surfaces. In addition, indwelling medical devices such as intravenous catheters increase the risk for invasive candidiasis by a number of mechanisms. First, catheters breach in the skin and underlying tissues, providing an easy portal of entry for microorganisms. Second, the foreign material of the catheter forms a barrier to the defence mechanisms of the host and to antimicrobial therapy. This barrier may be enhanced by the formation of biofilms by the infecting microorganism [37]. C. albicans makes rather complex metabolically active biofilms consisting of a basal blastospore layer with an overlying matrix of polysaccharides and hyphae [38]. Third, the nature of the infusion fluid, especially when it is parenteral nutrition fluid or highly concentrated sugar solution, contributes to the risk of Candida infection by promoting the growth of the fungus [39].

Among patients with normal neutrophil numbers and function the most important risk factors for invasive candidiasis are also systemic antibiotic therapy, the presence of indwelling medical devices (especially a central venous catheter) and total parenteral nutrition [3]. Major abdominal surgery, pancreatitis and renal insufficiency are additional risk factors [3,40,41]. Via the bloodstream, Candida spp. tend to lodge in various organs, the most serious localizations being the central nervous system and the endocardium [42,43]. As mentioned above, the host's army in these tissues consists of monocytes/exudate macrophages, tissue 
macrophages and neutrophils; $\mathrm{T}_{\mathrm{h}}$ cells and natural killer cells also play a role in the combat. In the interplay between these cells a series of cytokines, the most important being IL-1, tumour necrosis factor, IL-18 and interferon (IFN) $\gamma$, are essential to activate the candidacidal mechanisms (Fig. 4.). Because of the comorbidity and additional risk factors in these patients, these effector mechanisms often function suboptimally and this leads to the poor prognosis.

\section{Immunotherapy for candidiasis}

Despite the advent of potent new antifungal drugs, the prognosis of severe candidiasis, especially candidaemia, has not substantially improved in recent years [44]. Part of the explanation is that patients with invasive candidiasis often have severe and potentially fatal comorbidities and hence even very potent antifungal drugs may fail. If we consider the attributable mortality, which is in the order of $40 \%$ [41], the conclusion must be that there is room for improvement. Given the knowledge of host defence mechanisms presented in this paper it would be logical to follow the famous quote of Sir Ralph Bloomfield Bonington in George Bernard Shaw's play The Doctor's Dilemma: 'Stimulate the phagocytes!' This kind of approach, using either G-CSF, IL-1, IL-18 or IFN $\gamma$, has been undertaken in experimental animals and met with improved survival [45-49]; in humans, however, clinical trials are scarce. In a randomized trial in non-neutropenic patients with candidaemia, Kullberg et al. $[50,51]$ found that G-CSF significantly decreased the time to resolution of candidiasis, and patients treated with G-CSF who achieved an increased neutrophil count had improved survival.

As far as we know this study has never been repeated and G-CSF has not yet found its way into the treatment of invasive candidiasis. A randomized controlled clinical trial exploring the effects of recombinant IFN $\gamma$ is planned to start towards the end of 2010. In addition, it is time to explore other treatments based on the insights that have been acquired in the pathogenesis of severe Candida infections.

Funding: The author received an honorarium for writing this article. The funds for the honorarium were provided by Novartis AG, Switzerland and were handled by the organizing committee of the 4th European Conference on Bloodstream Infections for the publication of this supplement.

Competing interests: None.

Ethical approval: Not applicable. 


\section{References}

[1] Lilic D, Haynes K. Candida. In: Brown GD, Netea MG, editors. Immunology of fungal infections. Dordrecht: Springer; 2007, pp. 359-80.

[2] Pfaller MA, Diekema DJ. Epidemiology of invasive mycoses in North America. Crit Rev Microbiol 2010;36:1-53.

[3] Guery BP, Arendrup MC, Auzinger G, Azoulay E, Borges Sá M, Johnson EM, et al. Management of invasive candidiasis and candidemia in adult non-neutropenic intensive care unit patients: Part I. Epidemiology and diagnosis. Intensive Care Med 2009;35:55-62.

[4] De Bernardis F, Agatensi L, Ross IK, Emerson GW, Lorenzini R, Sullivan PA, et al. Evidence for a role for secreted aspartate proteinase of Candida albicans in vulvovaginal candidiasis. J Infect Dis 1990;161:1276-83.

[5] Schaller M, Bein M, Korting HC, Baur, S, Hamm G, Monod, M, et al. The secreted aspartyl proteinases Sap1 and Sap2 cause tissue damage in an in vitro model of vaginal candidiasis based on reconstituted human vaginal epithelium. Infect Immun 2003;71:3227-34.

[6] Shah DT, Glover DD, Larsen B. In situ mycotoxin production by Candida albicans in women with vaginitis. Gynecol Obstet Invest 1995;39:67-9.

[7] Soll DR. High-frequency switching in Candida albicans and its relations to vaginal candidiasis. Am J Obstet Gynecol 1988;158:997-1001.

[8] Sobel JD. Vulvovaginal candidosis. Lancet 2007;269:1962-71.

[9] Dennerstein GJ, Ellis DH. Oestrogen, glycogen and vaginal candidiasis. Aust N Z J Obstet Gynaecol 2001;41:326-8.

[10] Powell BL. Identification of a 173-estradiol-binding protein in Candida albicans and Candida (Torulopsis) glabrata. Exp Mycol 1984;8:304.

[11] Janeway CA Jr., Medzhitov R. Innate immune recognition. Annu Rev Immunol 2001;20:197-216.

[12] Takeuchi O, Akira S. Pattern recognition receptors and inflammation. Cell 2010;140:805-20.

[13] Netea MG, Brown GD, Kullberg BJ, Gow NA. An integrated model of the recognition of Candida albicans by the innate immune system. Nat Rev Microbiol 2008;6:67-78.

[14] Ferwerda B, Ferwerda G, Plantinga TS, Willment JA, van Spriel AB, Venselaar H, et al. Human dectin-1 deficiency and mucocutaneous fungal infections. N Engl J Med 2009;361:1760-7.

[15] Plantinga TS, van der Velden WJ, Ferwerda B, van Spriel AB, Adema G, Feuth T, et al. Early stop polymorphism in human DECTIN-1 is associated with increased candida colonization in hematopoietic stem cell transplant recipients. Clin Infect Dis 2009;49:724-32.

[16] Glocker EO, Hennigs A, Nabavi M, Schäffer AA, Woellner C, Salzer U, et al. A homozygous CARD9 mutation in a family with susceptibility to fungal infections. N Engl J Med 2009;361:1727-35.

[17] Van de Veerdonk FL, Marijnissen RJ, Kullberg BJ, Koenen HJ, Cheng SC, Joosten I, et al. The macrophage mannose receptor induces IL-17 in response to Candida albicans. Cell Host Microbe 2009;5:329-40.

[18] Hashimoto M, Hirota K, Yoshitomi H, Maeda S, Teradaira S, Akizuki S, et al. Complement drives Th17 cell differentiation and triggers autoimmune arthritis $\mathrm{J}$ Exp Med 2010;207:1135-43.

[19] O'Brien RL, Roark CL, Born WK. IL-17-producing gammadelta T cells. Eur J Immunol 2009;39:662-6. 
[20] Kao CY, Chen Y, Thai P, Wachi S, Huang F, Kim C, et al. IL-17 markedly upregulates beta-defensin-2 expression in human airway epithelium via JAK and NF-

kappaB signaling pathways. J Immunol 2004;173:3482-91.

[21] Guaní-Guerra E, Santos-Mendoza T, Lugo-Reyes SO, Terán LM.

Antimicrobial peptides: general overview and clinical implications in human health and disease. Clin Immunol 2010;135:1-11.

[22] Nath DS, Kandaswamy R, Gruessner R, Sutherland DE, Dunn DL, Humar A. Fungal infections in transplant recipients receiving alemtuzumab. Transplant Proc 2005;37:934-6.

[23] Milner JD, Brenchley JM, Laurence A, Freeman AF, Hill BJ, Elias KM, et al. Impaired $\mathrm{T}(\mathrm{H}) 17$ cell differentiation in subjects with autosomal dominant hyper-IgE syndrome. Nature 2008;452:773.

[24] Eyerich K, Foerster S, Rombold S, Seidl HP, Behrendt H, Hofmann H, et al. Patients with chronic mucocutaneous candidiasis exhibit reduced production of Th17associated cytokines IL-17 and IL-22. J Invest Dermatol 2008;128:2640-5.

[25] Van de Veerdonk FL, Marijnissen R, Joosten LA, Kullberg BJ, Drenth JP, Netea MG, et al. Milder clinical hyperimmunoglobulin $E$ syndrome phenotype is associated with partial interleukin-17 deficiency. Clin Exp Immunol 2009;159:57-64.

[26] Onishi RM, Gaffen SL. Interleukin-17 and its target genes: mechanisms of interleukin-17 function in disease. Immunology 2010;129:311-21.

[27] Sobel JD, Muller G, Buckley HR. Critical role of germ tube formation in the pathogenesis of candidal vaginitis. Infect Immun 1984;44:576-80.

[28] Latz E. The inflammasomes: mechanisms of activation and function. Curr Opin Immunol 2010;22:28-33.

[29] Netea MG, Nold-Petry CA, Nold MF, Joosten LA, Opitz B, van der Meer JH, et al. Differential requirement for the activation of the inflammasome for processing and release of IL-1 \{beta $\}$ in monocytes and macrophages. Blood 2009;113:2324-35.

[30] Segal BH, Bow EJ, Menichetti F. Fungal infections in nontransplant patients with hematologic malignancies. Infect Dis Clin North Am 2002;16:935-64.

[31] Davis SD, Schaller J, Wedgwood RJ. Job's Syndrome. Recurrent, "cold", staphylococcal abscesses. Lancet 1966;1(7445):1013-15.

[32] Van der Meer JWM, Kullberg BJ. Defects in host defense mechanisms. In: Rubin RH, Young LS, editors. Clinical approach to infections in the compromised host, 4th ed. New York: Plenum Press; 2003.

[33] Pitzalis C, Pipitone N, Perretti M.Regulation of leukocyte-endothelial interactions by glucocorticoids. Ann N Y Acad Sci 2002;966:108-18.

[34] Momcilović M, Miljković Z, Popadić D, Marković M, Savić E, Ramić Z, et al. Methylprednisolone inhibits interleukin-17 and interferon-gamma expression by both naive and primed T cells. BMC Immunol 2008;9:47.

[35] Holland SM. Chronic granulomatous disease. Clin Rev Allergy Immunol 2010;38:3-10.

[36] Liese J, Kloos S, Jendrossek V, Petropoulou T, Wintergerst U, Notheis G, et al. Long-term follow-up and outcome of 39 patients with chronic granulomatous disease. J Pediatr 2000;137:687-93.

[37] Ramage G, Mowat E, Jones B, Williams C, Lopez-Ribot J. Our current understanding of fungal biofilms. Crit Rev Microbiol 2009;35:340-55.

[38] Blankenship JR, Mitchell AP. How to build a biofilm: a fungal perspective. Curr Opin Microbiol 2006;9:588-94. 
[39] Kuwahara T, Shimono K, Kaneda S, Tamura T, Ichihara M, Nakashima Y. Growth of microorganisms in total parenteral nutrition solutions containing lipid. Int J Med Sci 2010;7:101-9.

[40] Ostrosky-Zeichner L, Sable C, Sobel J, Alexander BD, Donowitz G, Kan V, et al. Multicenter retrospective development and validation of a clinical prediction rule for nosocomial invasive candidiasis in the intensive care setting. Eur J Clin Microbiol Infect Dis 2007;26:271-276.

[41] Méan M, Marchetti O, Calandra T. Bench-to-bedside review: Candida infections in the intensive care unit. Crit Care 2008;12:204.

[42] Gottfredsson M, Perfect JR. Fungal meningitis. Semin Neurol 2000;20:307-22.

[43] Falcone M, Barzaghi N, Carosi G, Grossi P, Minoli L, Ravasio V, et al. Candida infective endocarditis: report of 15 cases from a prospective multicenter study. Medicine (Baltimore) 2009;88:160-8.

[44] Guery BP, Arendrup MC, Auzinger G, Azoulay E, Borges Sá M, Johnson EM, et al. Management of invasive candidiasis and candidemia in adult non-neutropenic intensive care unit patients: Part II. Treatment. Intensive Care Med 2009;35:206-14.

[45] Kullberg BJ, Netea MG, Curfs JH, Keuter M, Meis JF, van der Meer JWM. Recombinant murine granulocyte colony-stimulating factor protects against acute disseminated Candida albicans infection in nonneutropenic mice. J Infect Dis 1998; 177:175-81.

[46] Van't Wout JW, Van der Meer JWM, Barza M, Dinarello CA. Protection of neutropenic mice from lethal Candida albicans infection by recombinant interleukin1. Eur J Immunol 1988;18:1143-6.

[47] Kullberg BJ, van't Wout JW, van Furth R. Role of granulocytes in increased host resistance to Candida albicans induced by recombinant interleukin-1. Infect Immun 1990;58:3319-24.

[48] Kullberg BJ, van't Wout JW, Hoogstraten C, van Furth R. Recombinant interferon-gamma enhances resistance to acute disseminated Candida albicans infection in mice. J Infect Dis 1993;168:436-43.

[49] Stuyt RJ, Netea MG, van Krieken JH, van der Meer JWM, Kullberg BJ. Recombinant interleukin-18 protects against disseminated Candida albicans infection in mice. J Infect Dis 2004;189:1524-7.

[50] Kullberg BJ, Vandewoude K, Herbrecht R, Jacobs F, Aoun M, Kujath P. A double-blind, randomized, placebo-controlled Phase II study of filgrastim (recombinant granulocyte colony-stimulating factor) in combination with fluconazole for treatment of invasive candidemia in nonneutropenic patients. Abstracts of the $38^{\text {th }}$ Interscience Conference on Antimicrobial Agents and Chemotherapy; 24-27 September 1998; San Diego, CA, p. 479.

[51] Kullberg BJ, Oude Lashof A, Netea MG. Design of efficacy trials of cytokines in combination with antifungal drugs. Clin Infect Dis 2004;39:S218-23. 
[Figure legends]

Fig. 1. The major pathogen-associated molecular patterns (PAMPs) of the Candida albicans cell wall. The inner layers of the cell wall consist of a rigid skeleton of $\beta$-glucans and chitin, while at the surface, heavily mannosylated proteins (with both $\mathrm{N}$ - and $\mathrm{O}$-bound mannans) cover and shield the other PAMPs of the cell wall.

Fig. 2. Candida cells colonizing the epithelium are under the control of CD4 lymphocytes that have differentiated into $\mathrm{T}$ helper 17 lymphocytes (TH 17). These produce interleukin-17 (IL-17) and interleukin-22 (IL-22). IL-22 stimulates the epithelium to produce $\beta$-defensins, which are able to limit the outgrowth of the fungal cells.

Fig. 3. Extensive candidiasis of the feet of a 37-year-old man with chronic mucocutaneous candidiasis.

Fig. 4. When the epithelium is damaged by physical or chemical means the yeast is able to enter the submucosal tissue and start to form hyphae (the branched structures). The entry through the damaged epithelium will release chemotactic substances that evoke recruitment of polymorphonuclear leukocytes (PMN, i.e. neutrophils), which are able to phagocytose the yeasts and hyphae.

Fig. 5. Candida in its yeast form as well as its hyphal form encounters the various cells of the host defence. Resident macrophages $(\mathrm{M} \square)$ in the infected tissue produce a series of cytokines (interleukin (IL)-12, IL-18, and tumour necrosis factor (TNF) $\alpha$ ) to activate CD4 lymphocytes and natural killer (NK) cells to produce and secrete interferon- $\gamma$ (IFN $\gamma$ ) to enhance the fungicidal capacity of polymorphonuclear leukocytes (PMN) and monocytes (which become exudate macrophages). The resident macrophages also produce IL-1 $\beta$, IL-6 and IL-23, which in turn induce T helper 17 lymphocytes (TH17) to produce IL-17. The latter cytokine plays an important role in the attraction of neutrophils. 


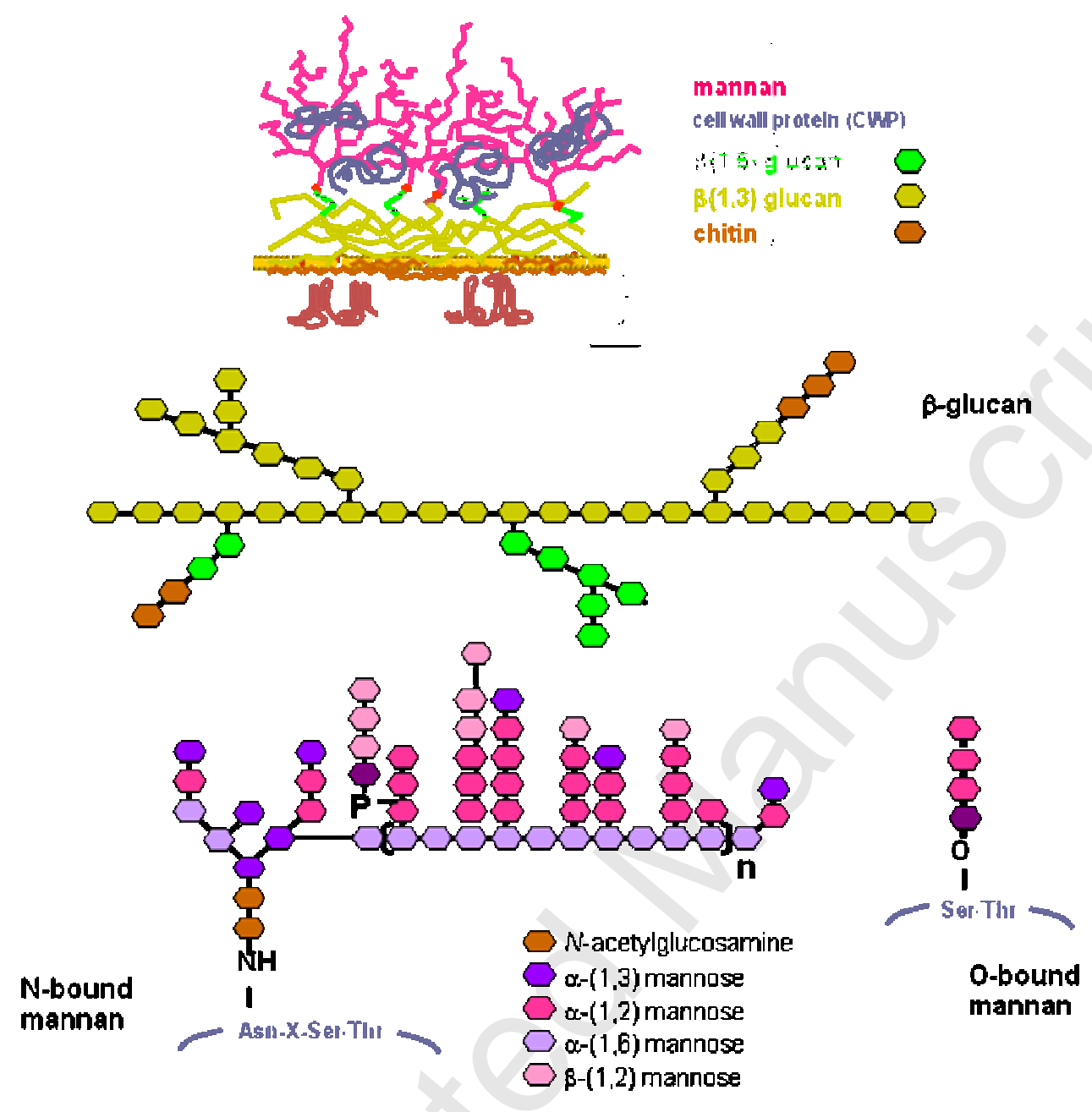




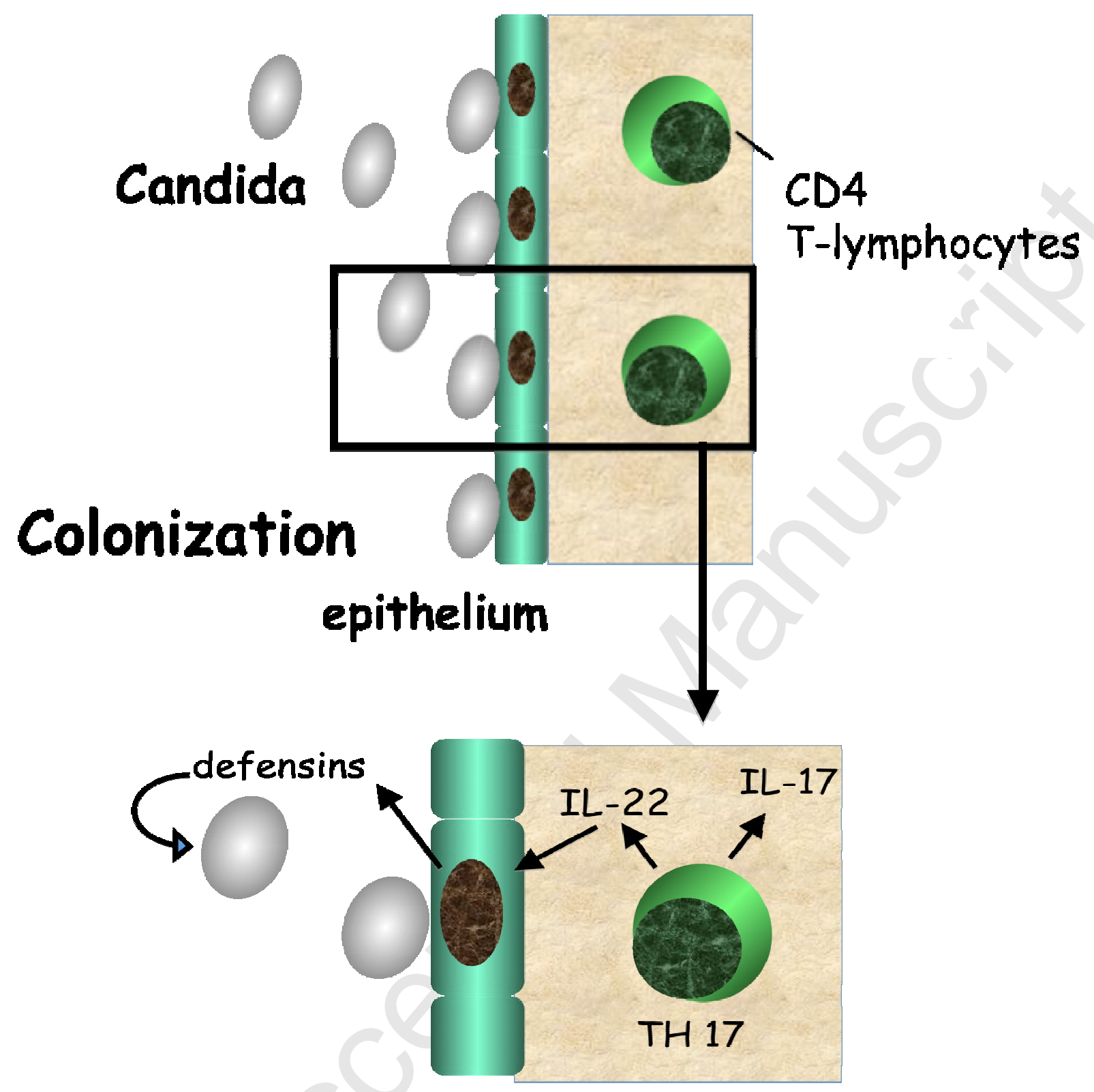




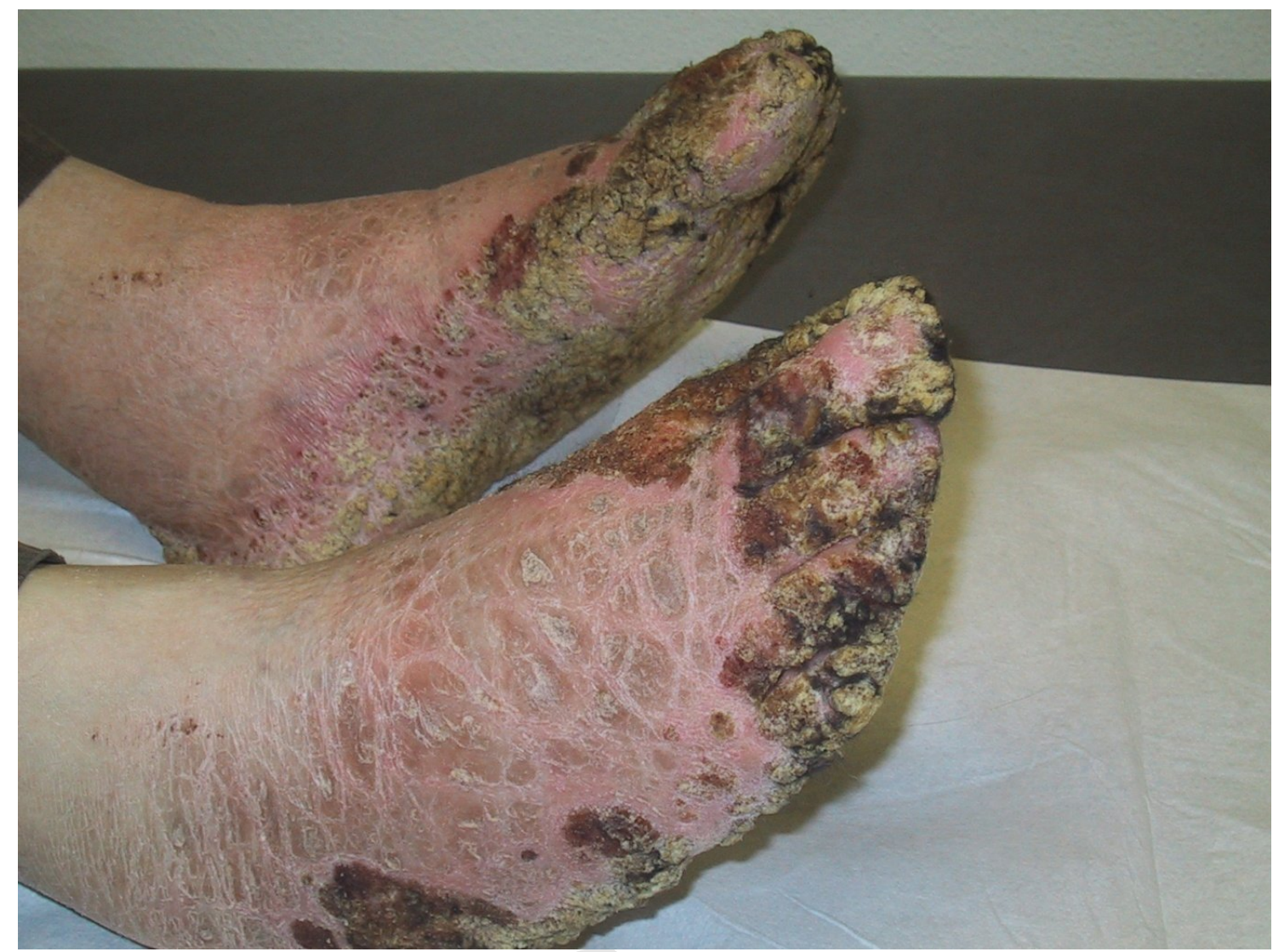

Page 13 of 15 


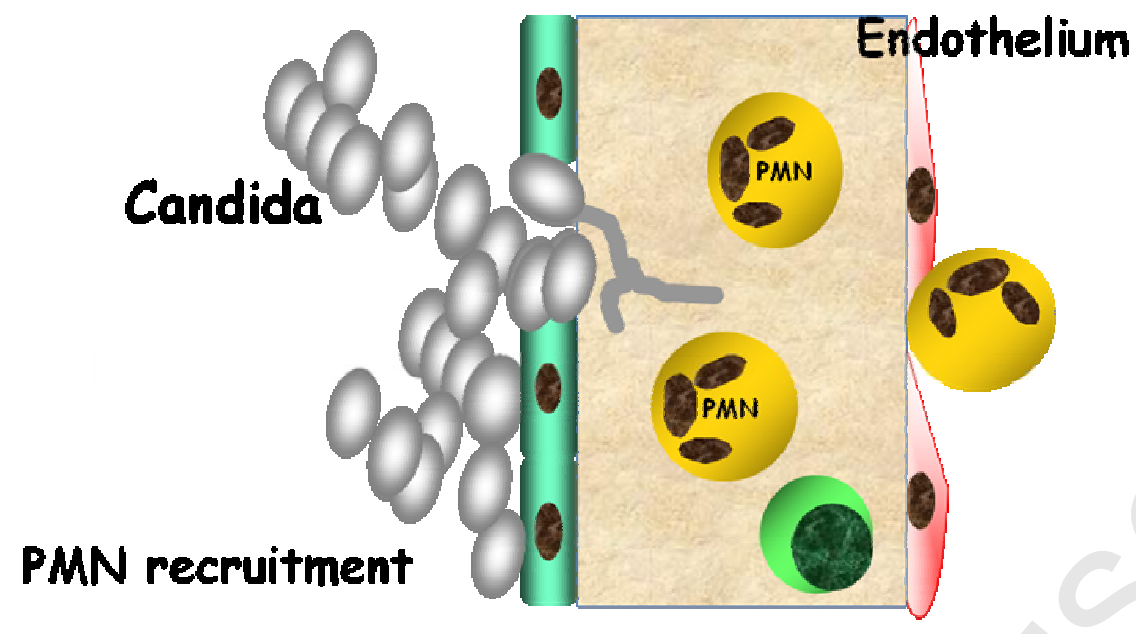




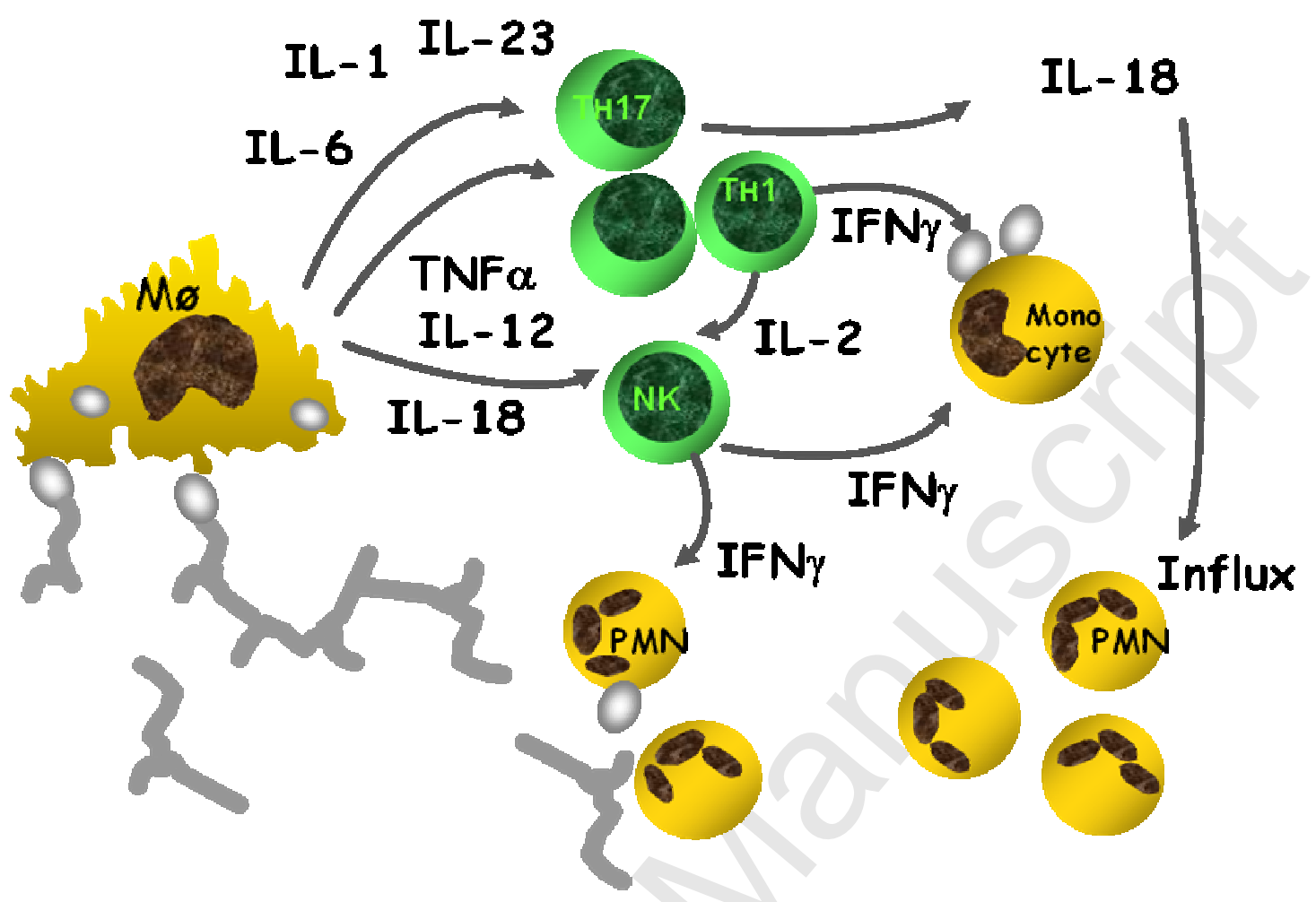

